\title{
Enfoque por competencias en la enseñanza superior. Breves reflexiones sobre la evaluación
}

\author{
Graciela Peralta \\ Email:gperalta@fce.unl.edu.ar \\ Viviana Cámara \\ Email:vcamara@fce.unl.edu.ar
}

\author{
Belquis Alaniz \\ Email:balaniz@fce.unl.edu.ar \\ Marta Nardoni \\ Email:mnardoni@fce.unl.edu.ar
}

Palabras clave

- competencias profesionales

- evaluación del aprendizaje

\section{Resumen}

En la Universidad la evaluación de los aprendizajes constituye una problemática que actualmente sigue siendo una tarea pendiente. Los estudios innovadores sobre evaluación educativa tanto la evaluación formativa (Coll y Onrubia, 1999) como la evaluación auténtica (Trillo Alonso, 2005) y en particular la evaluación de competencias (Barberá, 2005) responden a una lógica educativa que se construye sobre evidencias y sus abordajes permiten trascender de los problemas métricos de rendimiento y de acreditación para acercarse a los objetivos formativos de aprendizaje y desarrollo.

La evaluación auténtica propone una nueva forma de concebir los procesos de enseñanza, de aprendizaje y de evaluación. Todos estos sistemas plantean numerosos instrumentos- portafolios, proyectos, carpeta de evaluación; etc.- que son utilizados para exponer el nivel de progreso en los alumnos en determinadas habilidades cognitivas específicas a una disciplina o bien valúan el desarrollo progresivo de competencias complejas, generales $\mathrm{y} / 0$ profesionales.

Las autoras, en este trabajo, presentan el diseño y los resultados obtenidos de la aplicación de un portafolio creado para obtener evidencias y vivencias de un grupo de estudiantes de la cátedra de Matemática Básica de la Facultad de Ciencias Económicas de la Universidad Nacional del Litoral en una unidad disciplinar durante un período de tiempo y, a su vez, un análisis a priori de la factibilidad de aplicación del portafolio en el área de Matemática. 
Keywords

- professional competencies

- learning assessment

- portfolio

\section{Abstract}

At the University of assessment of learning is a problem which still remains a pending task.

The innovative research on educational assessment both formative assessment (Coll and Onrubia, 1999) and authentic assessment (Trillo Alonso, 2005) and in particular the assessment of competence (Barbera, 2005) correspond to a logic that is built on educational evidence and their approach can go beyond the metric of performance problems and accreditation to approach the learning objectives of learning and development.

Authentic assessment offers a new way of conceiving the processes of teaching, learning and assessment. All these systems pose numerous instruments, portfolios, projects, evaluation kit, etc .- are used to expose the level of achievement for students in certain cognitive skills specific to a discipline or valued the progressive development of complex skills, general and or professionals.

The authors, in this paper presents the design and the results of the implementation of a portfolio designed to obtain evidence and experiences of a group of students from the class of Basic Mathematics, Faculty of Economics at the Universidad Nacional del Litoral disciplinary unit for a period of time and, in turn, a priori analysis of the feasibility of application of the portfolio in the area of mathematics.

\section{Introducción}

El debate actual de la evaluación de los aprendizajes en la Universidad da cuenta que dicha problemática es una tarea pendiente. En ella intervienen cuestiones pedagógicas, epistemológicas, políticas, éticas y de poder pero además, las tradiciones instaladas históricamente están basadas y a su vez conforman sistemas de creencias - pocas veces explicitados o reconocidos- en los actores e instituciones acerca de qué es importante evaluar, para qué, porqué y al servicio de quién 0 quienes están operando dichas prácticas evaluativas.

En referencia a los actuales sistemas de evaluación dirigidos a los estudiantes universitarios, aparece una tradición -explica Bélair (2000)-, en la que "la evaluación es ante todo sumativa y responde a criterios de uniformización, que pretenden clasificar a los alumnos en función de los resultados obtenidos en exámenes basados en la repetición de contenidos transmitidos durante las clases". A lo que añade, que ese resulta ser además el mejor modo de controlar, de mantener la disciplina y de "motivar" a un grupo de alumnos.

En el debate actual acerca de las evaluaciones de aprendizaje se cuestiona, se interroga y se pone en duda las prácticas más frecuentes utilizadas en las Universidades.

Los cuestionamientos no sólo están referidos a los diferentes sistemas que se adoptan- exámenes parciales, trabajos prácticos u otras formas de producción durante el cursado; exámenes 0 trabajos finales por asignatura; las maneras de calificación en cuanto a promediar o no las diferentes instan- 